\title{
Irreversible diameter change of wood segments correlates with other methods for estimating frost tolerance of living cells in freeze-thaw experiment: a case study with seven urban tree species in Helsinki
}

\author{
Anna Lintunen ${ }^{1}$ - Teemu Paljakka ${ }^{1}$ - Anu Riikonen ${ }^{1}$ - Leena Lindén ${ }^{2}$. \\ Lauri Lindfors $^{1,3} \cdot$ Eero Nikinmaa $^{1}$ - Teemu Hölttä ${ }^{1}$
}

Received: 28 March 2015 / Accepted: 7 August 2015 /Published online: 8 September 2015

(C) INRA and Springer-Verlag France 2015

\begin{abstract}
- Key message We assessed tree frost tolerance using electrolyte leakage and a method based on irreversible diameter change of branches. It was shown that irreversible diameter change correlates with electrolyte leakage and USDA hardiness rating and is a good indicator of frost tolerance.

- Context The number of potential tree species for urban green planning is low in northern latitudes where cold tolerance is a critical factor. High cost of urban tree establishment calls for reliable and preferably non-destructive methods for determining their cold tolerance.

- Aims We studied the cellular damage occurring during freezing and thawing in branches of seven broadleaved tree species using electrolyte leakage and a method based on branch diameter changes.
\end{abstract}

Handling Editor: Gilbert Aussenac

Contribution of the co-authors A. Lintunen had the main responsibility for writing the paper and analyzing the data. T. Paljakka was responsible for the measurements and participated to data analysis. E. Nikinmaa, L. Lindén, T. Hölttä, and A. Riikonen planned the study design, and L. Lindfors participated in planning the diameter measurements. All authors contributed to writing of the manuscript.

Anna Lintunen

Anna.Lintunen@helsinki.fi

Teemu Paljakka

teemu.paljakka@helsinki.fi

Anu Riikonen

anu.riikonen@helsinki.fi

Leena Lindén

leena.linden@helsinki.fi

Lauri Lindfors

lauri.lindfors@helsinki.fi
- Methods Cellular damage in branches was studied during the cold-hardy stage in winter and the dehardening stage in early spring in laboratory conditions using both monitoring of frost-induced diameter changes and the common electrolyte leakage method during temperature decrease to $-25{ }^{\circ} \mathrm{C}$.

- Results Frost-induced irreversible diameter shrinkage correlated positively with electrolyte leakage. Out of the seven studied species, Quercus palustris and Crataegus monogyna had the highest frost tolerance during the dehardening stage in early spring, whereas Pterocarya fraxinifolia was the least frost tolerant.

- Conclusion Irreversible shrinkage of branch diameter due to freezing stress is a good and non-destructive method to indicate frost tolerance. It also correlates well with the USDA plant hardiness rating that is based on the minimum temperature range in which the studied species prevail in the USA.

Keywords Cold acclimation - Diameter variations · Frost damage $\cdot$ Electrolyte leakage

Eero Nikinmaa

eero.nikinmaa@helsinki.fi

Teemu Hölttä

teemu.holtta@helsinki.fi

Department of Forest Sciences, University of Helsinki, P.O. BOX 27, 00014 Helsinki, Finland

Department of Agricultural Sciences, University of Helsinki, P.O. BOX 27, 00014 Helsinki, Finland

Department of Physics, University of Helsinki, P.O. BOX 64, 00014 Helsinki, Finland 


\section{Introduction}

A variety of tree species are planted in cities worldwide, but the number of potential species for urban green planning in northern latitudes is low due to the need for the species to tolerate cold winter. Global warming may increase the choice of urban tree species also in the north, but cold tolerance is a critical factor during the transition phase from the current climate. Here, we present a study in which we assessed the frost tolerance of seven species newly experimented as urban trees in Helsinki, Finland, using the traditional electron leakage method (e.g., Dexter 1956; Flint et al. 1967; Prášil and Zámečník 1998) and a less-known method based on irreversible diameter change of wood axis (Améglio et al. 2001b, 2003a, b).

Water in tree xylem and other apoplastic spaces inevitably freezes when temperatures drop a few degrees below zero. The ice nucleation temperature of xylem sap depends on, e.g., osmotic concentration of the sap (Burke et al. 1976) and xylem anatomy (Lintunen et al. 2013), but thawing always occurs at approximately $0{ }^{\circ} \mathrm{C}$. The freezing of apoplastic sap causes two types of consequences for trees. The first consequence is freeze/thaw-induced embolism. Gases dissolved in the apoplastic sap form bubbles during freezing, and these bubbles are a risk of expanding and creating an embolism if thawing occurs when sap is under tension (Sperry and Sullivan 1992). Winter embolism causes long-term blockages to water transport and is known to decrease xylem conductivity (Sperry and Sullivan 1992; Sperry et al. 1994; Davis et al. 1999; Pittermann and Sperry 2003; Wheeler et al. 2005; Wilson and Jackson 2006; Charrier et al. 2014). The second important aspect of freezing stress experienced by trees is frostinduced cellular damage, i.e., cell membrane rupture caused by ice crystal formation within the living cells or through an extreme water potential difference between the living cells and the apoplast and the consequent extreme shrinking-swelling cycles of living cells upon freeze-thaw events (e.g., Ristic and Ashworth 1993; Thomashow 1998). A cell membrane rupture results in the leakage of symplastic contents into the apoplast and in permanent structural changes of the tissue in question.

Living cells cope with the freezing stress and avoid cellular damage either by deep supercooling or by extracellular freezing (e.g., George et al. 1982), depending on the species and tree organ. Deep supercooling refers to a unique adaptation of woody plants, where they dramatically suppress ice formation in specific tissues until homogeneous ice nucleation occurs at approximately $-38{ }^{\circ} \mathrm{C}$ (Kuroda et al. 2003; Wisniewski et al. 2004). Extracellular freezing is typical in the branches and stem of species grown in cold regions with isotherms beyond $-40{ }^{\circ} \mathrm{C}$ (Fujikawa and Kuroda 2000). Water is withdrawn from the living cells into the apoplast during extracellular freezing due to the water potential difference between the unfrozen cell sap and the apoplastic ice (Burke et al. 1976;
Levitt 1980; Pearce 1988, 2001). The outflow of water leads to cell shrinkage. The intracellular solute concentration is increased, and thus, the osmotic potential decreased. Decreased osmotic potential balances the decrease in water potential and lowers the equilibrium ice nucleation temperature of the cell sap (Taiz and Zeiger 2006). Dehydration of the elastic living tissue embedded in the xylem and living bark has been measured by monitoring diameter changes during freezing stress (Zweifel and Häsler 2000; Améglio et al. 2001a, 2003a, b).

Whatever the cold tolerance strategy of a species, winter acclimation is essential for this tolerance. Winter acclimation is the process through which plants prepare themselves for winter conditions (Weiser 1970) and become cold hardy. The winter acclimation capacity is crucial for the survival of trees growing in boreal and temperate regions (Sarvas 1972). Winter acclimation requires a programmed and integrated genetic capacity to activate the appropriate mechanisms needed to withstand harsh winter conditions (Thomashow 1999). Winter acclimation mechanisms include biochemical, physiological, and metabolic functions affecting, e.g., tissue water content (Gusta et al. 2004; Charrier and Améglio 2011; Charrier et al. 2013b), soluble sugar concentrations (Morin et al. 2007; Charrier et al. 2013b), production of freezing avoiding proteins in the symplast, and the permeability and fluidity of cell membranes (Thomashow 1998, 1999; Bohn et al. 2006; Uemura and Steponkus 2003; Uemura et al. 2006).

Améglio et al. (2001b) first presented the idea to use stem diameter variations to test frost hardiness over a decade ago. The method was successfully tested with Juglans regia L. (Améglio et al. 2003a) and Rosa hybrida L. (Améglio et al. 2003b). In the latter paper, stem diameter variations were analyzed together with electrolyte leakage (Dexter 1956; Flint et al. 1967; Prášil and Zámečník 1998), and a similar trend in frost hardiness was found in the course of the season with both measures (Améglio et al. 2003b). Since then, the method has been rarely used. Our aim was to compare irreversible diameter change and electrolyte leakage to measure frost tolerance in branches of seven broadleaved tree species in urban boreal environment. We measured frost-induced reversible and irreversible diameter variations during a temperature decrease to $-25{ }^{\circ} \mathrm{C}$ and subsequent thawing, electrolyte leakage at -17 and $-25{ }^{\circ} \mathrm{C}$, and ice nucleation temperature of the apoplastic sap. We hypothesized that the diameter variations upon freezing and thawing would reflect changes in the volume of living cells within the phloem and xylem, and a varying degree of electrolyte leakage should show up as irreversible frost-induced dimensional changes of the branches, as the membrane rupture would disable cell swelling upon thawing to its pre-freezing dimensions. We finally compared our frost tolerance results 
with the available classification to cold hardiness zones based on the minimum temperature range in which species prevail in the USA. The results of this study offer information on the frost tolerance and, thus, suitability of the studied species as street trees in Helsinki; these species are successfully grown, e.g., in southern Sweden.

\section{Material and methods}

\subsection{Study material}

Our set of trees tested included seven taxa (Table 1) successfully grown as urban street trees in southern Sweden (Bengtsson 1998), while having rarely been planted in Finland. The eighth taxon was a columnar clone of Sorbus aucuparia originating in southern Finland (Table 1). All trees are deciduous broadleaved species, although Ginkgo biloba is a gymnosperm with leaves instead of needles (Doyle and Donoghue 1992). The trees were planted in spring 2012 along an ordinary street in a residential area in Helsinki $\left(60^{\circ} \mathrm{N}, 25^{\circ} \mathrm{E}\right)$, located on the southern coast of Finland. The trees were acquired from Billbäcks $\left(58^{\circ} \mathrm{N}, 15^{\circ} \mathrm{E}\right)$ and Stångby $\left(55^{\circ} \mathrm{N}, 13^{\circ}\right.$ E) nurseries in Sweden, except for $S$. aucuparia, which was purchased from the Finnish Viksten's Nursery $\left(60^{\circ} \mathrm{N}, 23^{\circ} \mathrm{E}\right)$. Average tree height was $4.6 \mathrm{~m}$ at the time of the planting.

A branch was collected from three to six cold-hardy trees per species (Table 1) in February 2013 and another branch from the same trees during the dehardening stage at the beginning of April 2013. As we only had two G. biloba trees, we collected a total of three branches from these two individuals both in February and April. The total number of sample branches was 58. The sample branches were approximately $0.7 \mathrm{~m}$ long and at least $10 \mathrm{~mm}$ in base diameter. The sample branches were collected from the lower crown. The average and minimum daily temperatures prior to sampling in January were -4.9 and $-17{ }^{\circ} \mathrm{C}$ and, for other months, $-1.8^{\circ} \mathrm{C}$ and $-6.5{ }^{\circ} \mathrm{C}$ February, $-5.2{ }^{\circ} \mathrm{C}$ and $-10{ }^{\circ} \mathrm{C}$ March, and $3.1{ }^{\circ} \mathrm{C}$ and $-0.5{ }^{\circ} \mathrm{C}$ April, respectively.

Post cutting, the branches were brought to the laboratory in a plastic bag. Five branch segments were cut from each sample branch for different measurements: one segment each for the measurement of the apoplastic ice nucleation temperature (3-6 segments per species), three segments for the electrolyte leakage measurement (9-18 segments per species), and one segment for the diameter change measurements (always 3 segments per species). The branch segments originating from each sample branch were frozen in the same freezing

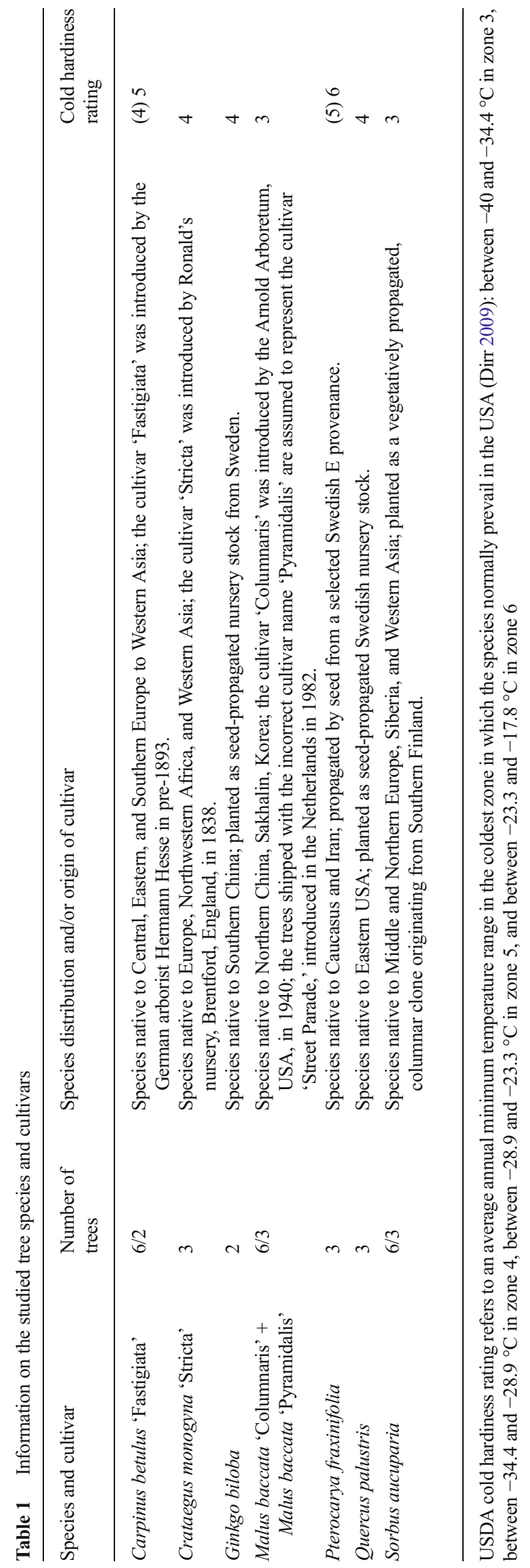


experiment; i.e., the freezing rate was similar for all measurements performed for one sample branch.

\subsection{Branch diameter variations}

Freezing experiments were conducted in a climate chamber (Weiss Umwelttechnik WK11 -340/40, Wien, Austria) with a 7.5-cm-long (diameter $0.6-1.1 \mathrm{~cm}$ ) branch segment per sample branch. The temperature was decreased from room temperature down to $-25{ }^{\circ} \mathrm{C}$ at a rate of $20{ }^{\circ} \mathrm{C}$ per hour and then raised up to $+5{ }^{\circ} \mathrm{C}$ in half an hour. Thermocouples (T-type) measured the under-bark xylem temperature and the ambient temperature from the climate chamber. Freezing of xylem sap could be detected from the freezing exotherm, i.e., a sudden increase in xylem temperature in relation to ambient air temperature due to the energy released from freezing (Burke et al. 1976).

Diameter over bark was measured using a linear displacement transducer (LVDT; model AX/5.0/S, Solartron, West Sussex, UK). The LVDT sensor and the $7.5-\mathrm{cm}$-long branch segment were attached to an aluminum frame with screws; the branch was attached from both ends. The sensor head was set to rest on the bark surface. We tested the thermal expansion effect of the frame on the measurements by replacing the sample branch with a glass pole: thermal expansion caused $0.63-\mu \mathrm{m}$ shrinkage per $1{ }^{\circ} \mathrm{C}$ decrease of temperature, which was taken into account in the results. We used the diameter shrinkage to branch diameter percentage to describe both reversible and irreversible shrinkages, as diameter shrinkage correlates with branch diameter (Améglio et al. 2001a). Reversible diameter shrinkage (DS reversible $_{\text {e }}$ was used to describe tissue elastic amplitude during the freezing experiment and irreversible diameter shrinkage $\left(\mathrm{DS}_{\text {irreversible }}\right)$ to describe the more permanent frost-induced shrinkage of the branch (Fig. 1). $\mathrm{DS}_{\text {total }}$ is the total diameter shrinkage, i.e., the sum of $\mathrm{DS}_{\text {reversible }}$ and $\mathrm{DS}_{\text {irreversible. }}$

\subsection{Electrolyte leakage}

The damage rate of the living tissue can be determined by measuring the tissue's electrolyte leakage as a percentage of its total electrolyte content (Dexter 1956; Flint et al. 1967; Prášil and Zámečník 1998).

The three sample branch segments cut for the electrolyte leakage experiments were taken from the previous growing season internode of the branch main axis. Each three segment was further cut in the laboratory into three 0.5-to 1$\mathrm{cm}$-long samples: one of each for the control, the temperature decrease to $-17^{\circ} \mathrm{C}$, and the temperature decrease to $-25^{\circ} \mathrm{C}$. The test temperature of $-25^{\circ} \mathrm{C}$ was selected as that

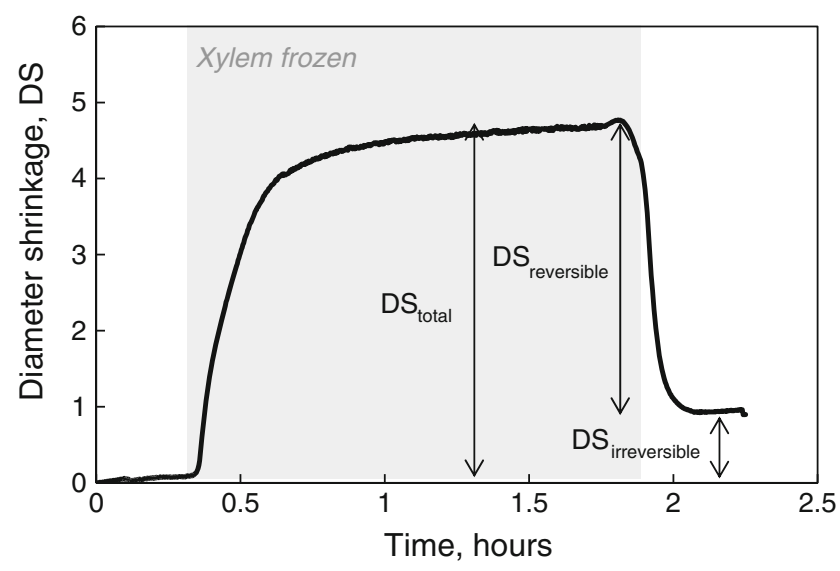

Fig. 1 Time series of one freezing experiment repetition with a Pterocarya fraxinifolia branch during cold-hardy stage. Diameter shrinkage to branch diameter percentage (DS) is shown. The terminology used regarding total diameter shrinkage $\left(\mathrm{DS}_{\text {total }}\right)$, reversible diameter shrinkage $\left(\mathrm{DS}_{\text {reversible }}\right)$, and irreversible diameter shrinkage (DS irreversible $)$ is introduced. Gray area refers to the period when xylem sap is frozen

is a temperature typically measured in Helsinki during the coldest winter days each year. The test temperature of $-17^{\circ} \mathrm{C}$ was selected to verify the results and to be between the freezing point and the target temperature $-25^{\circ} \mathrm{C}$. After cutting, the samples were sealed in glass tubes to inhibit evaporation, but the tubes were reopened at the beginning of the freezing experiment to ensure free temperature equilibrium. Freezing was performed in a climate chamber as described above. The samples for the electrolyte leakage measurement at $-17{ }^{\circ} \mathrm{C}$ were removed from the chamber when the xylem temperature reached $-17^{\circ} \mathrm{C}$.

The control $\left(R_{0}\right)$ and frozen samples $\left(R_{\mathrm{t}}\right)$ were rinsed with deionized water to remove any impurities. The samples were next resealed in the plastic tubes with $10 \mathrm{ml}$ of deionized water and shaken on a horizontal shaker at 120 cycles $\min ^{-1}$ at room temperature for $24 \mathrm{~h}$. Electrical conductivity was next measured from the tubes using a conductivity meter (Jenway 4010, Dunmow, UK). All the samples were finally autoclaved for approximately $20 \mathrm{~min}$ in $121^{\circ} \mathrm{C}$ and pressure of 2.04 bars and reshaken at room temperature $\left(120\right.$ cycles $\left.\mathrm{min}^{-1}\right)$, and electrical conductivity was measured to record the maximal conductivity.

The relative conductivities of the control and frozen samples were determined by dividing the electrical conductivity measured before autoclaving, with electrical conductivity measured after autoclaving. The frost-induced tissue damage was expressed as an index of injury $(I)$, calculated as proposed by Flint et al. (1967):

$I=\left(R_{t}-R_{0}\right) /\left(1-R_{0}\right)$

Relative conductivity is used to avoid the sample size effect on the results, whereas the index of injury reduces the 
unwanted effect of tissue differences on the electrolyte concentrations and the effect of electrolytes leaking from cut surfaces (Dexter 1956; Prášil and Zámečník 1998).

\subsection{Statistical analysis}

Results for the two Malus baccata cultivars were pooled, as the results were very similar for both cultivars of the species. Dependences among different freezing responses were analyzed using linear modeling (GLM procedure, SAS Institute, Cary, NC, USA). This method uses least squares to fit general linear models to the data. The data fulfilled assumptions of normality and homogeneity residual distribution except for the $\mathrm{DS}_{\text {reversible }}$ and $\mathrm{DS}_{\text {irreversible, }}$ which were square root transformed.

GLM procedure was also used for analyzing the possible effects of class variables season and tree species on the freezing responses. We used Tukey's $T$ test to compare the freezing responses between different species. Freezing responses between species were analyzed separately for winter and early spring data, except for the analysis regarding ice nucleation temperature of xylem sap that did not depend on the season.

The definition of statistical significance is $P<0.05$ throughout the paper.

\section{Results}

\subsection{Linkages among the freezing responses}

Samples with high electrolyte leakage at $-25{ }^{\circ} \mathrm{C}$ showed higher electrolyte leakage also at $-17^{\circ} \mathrm{C}(P=0.0003$, Fig. 2a).

During the temperature decrease to $-25^{\circ} \mathrm{C}, \mathrm{DS}_{\text {irreversible }}$ increased with increasing electrolyte leakage at $-25^{\circ} \mathrm{C}(P=$ 0.0015 , Fig. 2b). $\mathrm{DS}_{\text {irreversible }}$ and $\mathrm{DS}_{\text {reversible }}$ did not correlate with each other; neither did $\mathrm{DS}_{\text {reversible }}$ and electrolyte leakage.

\subsection{Freezing response differences between seasons and species}

The ice nucleation temperature of the apoplastic sap did not differ between winter and early spring but did differ $(P=$ 0.004 ) between species: Quercus palustris had the lowest ice nucleation temperature (Table 2).

The average electrolyte leakage of the seven species was higher during the dehardening than the cold-hardy stage $(P=$ 0.0011 at $-17^{\circ} \mathrm{C}$ and $P<0.0001$ at $-25^{\circ} \mathrm{C}$, Fig. 3). The average index of injury at $-17{ }^{\circ} \mathrm{C}$ was $0.045(95 \%$ confidence interval, hereafter $\mathrm{CI} \pm 0.027$ ) during winter and 0.104 ( $\mathrm{CI} \pm$ 0.023 ) during early spring, while the corresponding figures at $-25^{\circ} \mathrm{C}$ were $0.118(\mathrm{CI} \pm 0.036)$ and $0.235(\mathrm{CI} \pm 0.030)$, respectively. No significant differences were observed in the electrolyte leakage between species during the cold-hardy stage (Fig. 3). Pterocarya fraxinifolia showed the highest electrolyte leakage during the dehardening stage, whereas Q. palustris and Crataegus monogyna 'Stricta' were the most frost-tolerant taxa with least leakage (Fig. 3).

The mean $\mathrm{DS}_{\text {reversible }}$ and $\mathrm{DS}_{\text {irreversible }}$ of the seven tree species were significantly different between the cold-hardy and dehardening stages (Fig. 4). $\sqrt{ } \mathrm{DS}_{\text {reversible }}$ averaged 1.05 $(\mathrm{CI} \pm 0.23)$ during the cold-hardy stage and $0.64(\mathrm{CI} \pm 0.24)$ during the dehardening stage. $\sqrt{ } \mathrm{DS}_{\text {irreversible }}$ averaged 0.58 $(\mathrm{CI} \pm 0.13)$ during the cold-hardy stage and $0.97(\mathrm{CI} \pm 0.14)$ during the dehardening stage. No differences between species regarding $\mathrm{DS}_{\text {reversible }}$ and $\mathrm{DS}_{\text {irreversible }}$ were found during winter (Fig. 4), while both $\mathrm{DS}_{\text {reversible }}$ and $\mathrm{DS}_{\text {irreversible were }}$ highest in P. fraxinifolia and lowest in C. monogyna 'Stricta' during early spring (Fig. 4).

The freezing injury parameters were compared with the USDA cold hardiness rating (Dirr 2009) for each species. A clear correlation $(P=0.044)$ was found between the $\mathrm{DS}_{\text {irreversible }}$ measured during the cold-hardy stage and the USDA cold hardiness rating (Fig. 5). The electrolyte leakage denoted with the index of injury did not significantly correlate $\left(R^{2}=0.27\right)$ with the hardiness rating.

\section{Discussion}

We measured frost tolerance in seven broadleaved species grown as street trees in an urban boreal environment in Helsinki, Finland $\left(60^{\circ} \mathrm{N}, 25^{\circ} \mathrm{E}\right)$. The results demonstrated that frost-induced electrolyte leakage and irreversible shrinkage (DS irreversible $_{\text {e }}$ are connected as suggested by Améglio et al. (2003b). Electrolyte leakage indicates damage in the elastic living tissue caused by cell membrane rupture (Steponkus 1984) and cell sap leakage into the apoplast (e.g., Sutinen et al. 1992; Ristic and Ashworth 1993; Charrier and Améglio 2011). Cells permanently lose their turgor if freezing leads to cell membrane rupture. This should result in permanent tissue shrinking as we hypothesized and observed.

Both electrolyte leakage and irreversible shrinkage were clearly higher during the dehardening stage than in the coldhardy stage. This result is in line with earlier studies that have measured electrolyte leakage (e.g., Charrier et al. 2013a, b), irreversible shrinkage (Améglio et al. 2001a, b, 2003a), or both (Améglio et al. 2003b). Trees experience metabolic and physical changes during winter acclimation (Weiser 1970), e.g., compositional, structural, and functional cell membrane changes involving membrane lipids and proteins (Thomashow 1998, 1999; Bohn et al. 2006; Uemura and Steponkus 2003; Uemura et al. 2006) that make them more frost-tolerant. The conversion of starch to soluble sugars (Morin et al. 2007; Charrier and Améglio 2011; Charrier et al. 2013b) and decreased tissue water content (Gusta et al. 
Fig. 2 Correlation between electrolyte leakage at $-25^{\circ} \mathrm{C}$ and a electrolyte leakage at $-17^{\circ} \mathrm{C}$ $(P=0.0003)$ and $\mathbf{b}$ irreversible branch diameter shrinkage $\mathrm{DS}_{\text {irreversible }}(P=0.0015)$ during a temperature decrease to $-25^{\circ} \mathrm{C}$. Electrolyte leakage is denoted with an index of injury as described by Flint et al. (1967). Irreversible branch diameter shrinkage has been square root transformed. The whole data set is presented in the figure at tree level. Linear regression lines are shown a
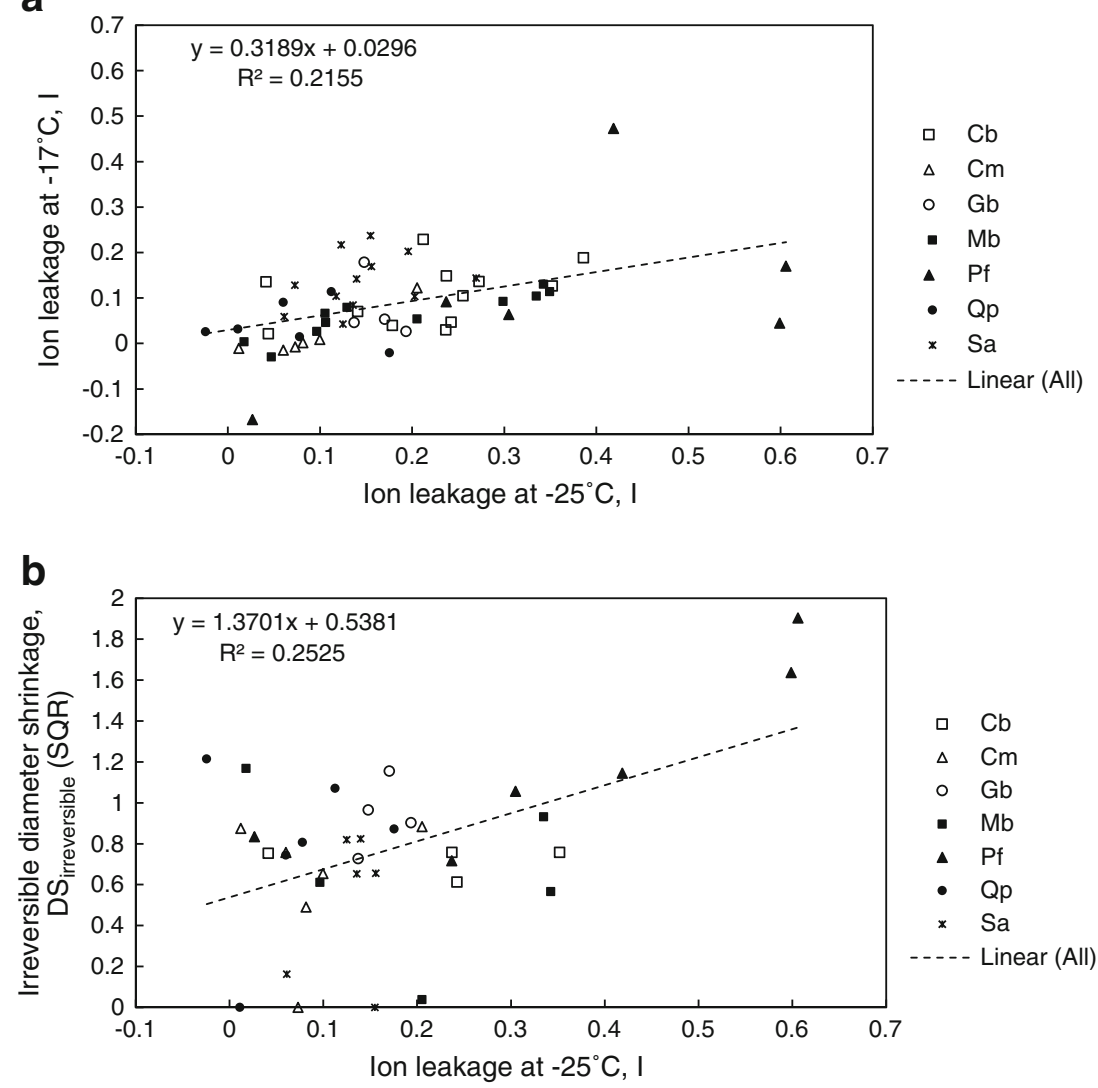

2004; Charrier and Améglio 2011; Charrier et al. 2013b) have also been connected to hardening.

In addition to irreversible diameter changes, the trees experienced reversible diameter shrinkage during freezing stress, as most of the total branch diameter shrinkage was restored after thawing. Similar results have been found for J. regia (Améglio et al. 2001b, 2003a), Picea abies (Zweifel and Häsler 2000), and R. hybrida (Améglio et al. 2003b). Irreversible diameter shrinkage did not correlate with reversible diameter shrinkage. Reversible frost-induced diameter shrinkage indicates tissue elasticity. Wintertime elasticity of living tissue is an important characteristic in cold regions, where low temperatures cause extremely low water potentials in frozen xylem. Extracellular freezing (George et al. 1982) is vital in these circumstances to ensure the survival of living cells and requires living cells to have the ability to lose water into the apoplast and shrink, but also to swell back to their original dimensions without structural damages when thawing. Results showed that unlike irreversible diameter changes indicating cellular damage, $\mathrm{DS}_{\text {reversible }}$ was higher in cold-hardy trees compared to trees at the dehardening stage as also reported for $J$. regia (Améglio et al. 2001b, 2003a) and R. hybrida (Améglio et al. 2003b). Decreased tissue elasticity likely plays a role in the cell damage of non-acclimated trees.

Table 2 Mean apoplastic ice nucleation temperature for each studied species with standard errors

\begin{tabular}{lcr}
\hline Tree species and cultivar & Mean freezing temperature $\left({ }^{\circ} \mathrm{C}\right)$ \\
\cline { 2 - 3 } & Winter & Early spring \\
\hline Carpinus betulus 'Fastigiata' & $-6.0( \pm 0.4)$ & $-5.9( \pm 0.7)$ \\
Crataegus monogyna 'Stricta' & $-6.1( \pm 0.8)$ & $-5.5( \pm 0.2)$ \\
Ginkgo biloba & $-6.8( \pm 0.9)$ & $-6.2( \pm 0.6)$ \\
Malus baccata 'Columnaris' + Malus baccata 'Pyramidalis' & $-4.7( \pm 0.7)$ & $-6.1( \pm 0.3)$ \\
Pterocarya fraxinifolia & $-7.3( \pm 1.4)$ & $-5.5( \pm 1.1)$ \\
Quercus palustris & $-10.3( \pm 0.01)$ & $-7.5( \pm 1.6)$ \\
Sorbus aucuparia & $-5.9( \pm 0.8)$ & $-6.5( \pm 0.2)$ \\
\hline
\end{tabular}


Fig. 3 Mean index of injury at a $-17^{\circ} \mathrm{C}$ and $\mathbf{b}-25^{\circ} \mathrm{C}$ is shown for winter and early spring for each species with standard error. Electrolyte leakage is denoted with an index of injury as described by Flint et al. (1967). Significant differences $(P<0.05)$ among tree taxa in early spring measurements are denoted with different letters

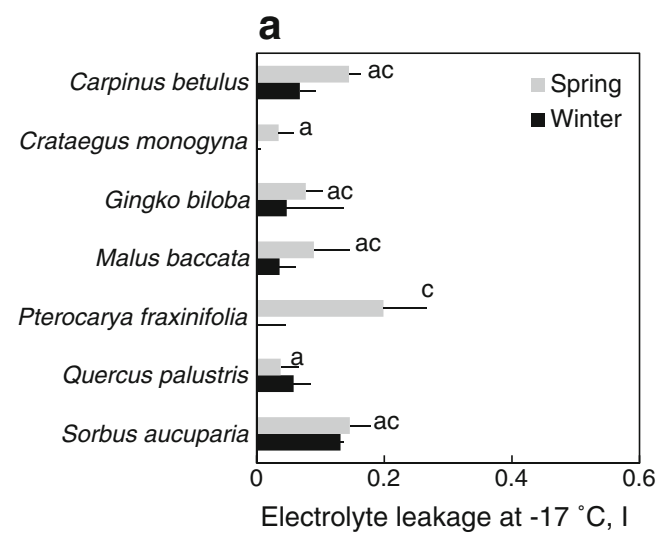

b

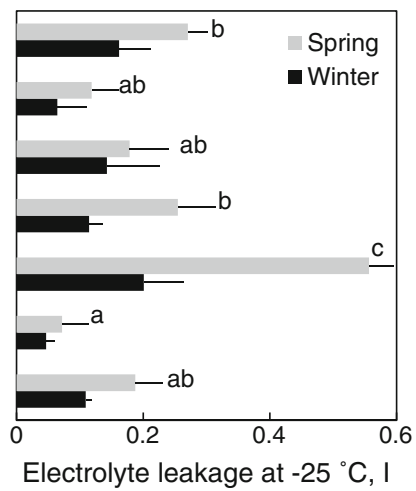

Ice nucleation is always a stochastic phenomenon, which is visible in the rather random variation of ice nucleation temperatures of xylem sap between winter and early spring measurements. Also, Pramsohler et al. (2012) found no seasonal differences in the apoplastic ice nucleation temperature in Malus domestica. Seasonal differences could be caused by seasonal changes in the osmotic concentration of the apoplastic sap (Charrier et al. 2013a). However, we did record statistical differences in apoplastic ice nucleation temperatures between some of the studied species, suggesting a linkage to xylem anatomy as small size of xylem conduits has been connected to low ice nucleation temperature through the size of impurities penetrating the cells and acting as ice nuclei that catalyze the formation of ice (Lintunen et al. 2013). A fairly low apoplastic ice nucleation temperature could be an advantage in cold environments, where trees have to tolerate low freezing temperatures, as it decreases the number and length

\section{a}

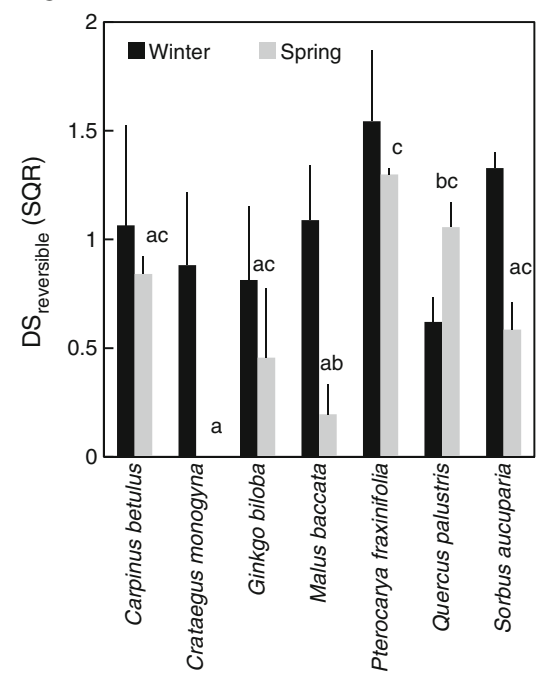

Fig. 4 Branch diameter shrinkage during a temperature decrease to $-25{ }^{\circ} \mathrm{C}$ in winter and early spring for seven taxa. a Mean reversible diameter shrinkage $\mathrm{DS}_{\text {reversible }}$ and $\mathbf{b}$ mean irreversible shrinkage $\mathrm{DS}_{\text {irreversible. }}$ Reversible and irreversible branch diameter shrinkages are square root transformed (SQR). The bars denote standard error. of the freeze-thaw cycles that the tree has to experience (Lintunen et al. 2013). However, an excessively low apoplastic ice nucleation temperature can also be harmful to trees, as it increases the risk of intracellular freezing of the living cells that are left without the benefits of extracellular freezing (Sakai and Larcher 1987). Such behavior may be linked to deep supercooling of xylem parenchyma that is often observed in trees originating from regions where temperature does not drop below $-40{ }^{\circ} \mathrm{C}$ (Kuroda et al. 2003). Unlike apoplastic ice nucleation temperature (i.e., high-temperature exotherm), symplastic ice nucleation temperature (i.e., lowtemperature exotherm (LTE)) typically has a clear decreasing trend during the process of winter acclimation (e.g., Lindstrom et al. 1995). We did not detect LTE in our experiments (although absence of LTE cannot be verified due to small oscillation of temperature near the target temperature in the climate chamber).

\section{b}

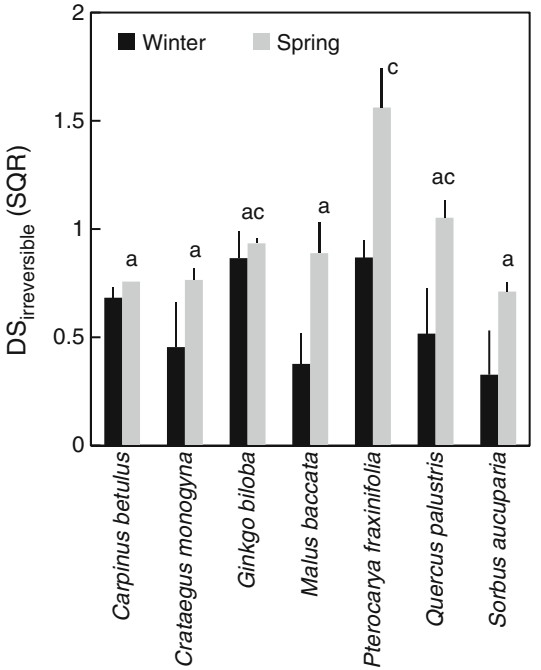

Differences between seasons were statistically significant: $\sqrt{ } D S_{\text {reversible }}$ $P=0.016 ; \sqrt{ } \mathrm{DS}_{\text {reversible }} P=0.0002$. Statistically significant differences between species are denoted with different letters in the early spring data (no statistically significant differences between species were found in the winter data) 


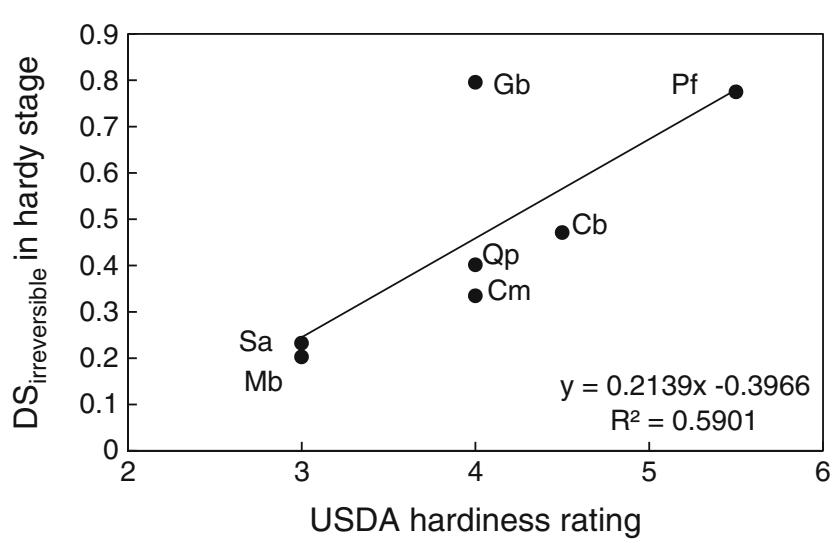

Fig. 5 Relationship between the irreversible diameter shrinkage $\mathrm{DS}_{\text {irreversible }}$ during a temperature decrease to $-25^{\circ} \mathrm{C}$ measured in coldhardy branches and hardiness rating that is based on the minimum temperature range in which the species prevail in the USA $(P=0.044$; Dirr 2009). The highest cold hardiness is indicated with the smallest number in the rating system. Each species is denoted with the first letters of their scientific names: Carpinus betulus $(\mathrm{Cb})$, Crataegus monogyna (Cm), Ginkgo biloba (Gb), Pterocarya fraxinifolia (Pf), Quercus palustris (Qp), Malus baccata (Mb), and Sorbus aucuparia (Sa)

The best frost tolerance as measured in terms of electrolyte leakage in both the cold-hardy and dehardening stage was displayed by $Q$. palustris and C. monogyna 'Stricta'. These frost-tolerant species are native to northern latitudes of Europe (C. monogyna) and USA (Q. palustris). Q. palustris also showed some unexpected results: it had the lowest ice nucleation temperature among the studied species despite usually having exceptionally large vessels, and unlike other species, it showed lower elastic amplitude during the cold-hardy compared to dehardening stage. In addition to frost hardiness of living cells, sensitivity to freeze-thaw embolism is an essential frost resistance mechanism for trees (Charrier et al. 2013a). Freeze-thaw embolism is connected to the freezing stress experienced by the living cells via the ability of the living cells to refill xylem conduits (Charrier et al. 2013a) and, in theory, via the amount of ice content in the apoplast and hence the area connecting symplastic water and apoplastic ice fronts. Genus Quercus is known for its large-vesseled ring-porous xylem that "sacrifices" most of the vessels each winter for winter embolism and transports water during the next growing season with large, newly formed vessels (Cochard and Tyree 1990; Sperry and Sullivan 1992; Sperry et al. 1994). This suggests that the large vessels of $Q$. palustris were already embolized during winter, since embolism develops more easily in wider vessels (Cochard and Tyree 1990; Davis et al. 1999; Pittermann and Sperry 2003; Charrier et al. 2014). Low ice nucleation temperature might be caused by the lack of water in the xylem during winter, as it is known that tissue water status affects the supercooling capacity (Burke et al. 1976; Goldstein et al. 1985). Lack of water in the large vessels would result in a low ice nucleation temperature of the apoplastic sap in the remaining small intact conduits
(Lintunen et al. 2013) and only minor need for elastic shrinkage during winter due to the reduced connection area between symplastic water and apoplastic ice fronts. Low branch water content during freezing stress has been connected to low electrolyte leakage in earlier studies (Charrier and Améglio 2011; Charrier et al. 2013b). It is possible that winter embolism gives advantage for the living tissue in $Q$. palustris to tolerate frost stress which can be seen as low ion leakage.

Our results suggest that $P$. fraxinifolia was the study species most vulnerable to freezing, which responded to low freezing temperatures with the highest electrolyte leakage and highest irreversible shrinkage during the dehardening stage. However, reversible shrinkage indicating high tissue elasticity was also the highest in P. fraxinifolia. This result shows that it is challenging to interpret the results regarding a shrinkage comparison between species without knowing the species-specific maximum potential shrinkage, as the total volume of living cells in the branch tissue varies between species. Improvement for future study would be suggested by the method Gelista ${ }^{\mathrm{TM}}$ (Améglio et al. 2003a), where the loss of diameter after one cycle of freeze-thaw at a given temperature is compared to the maximal diameter loss. To obtain the maximal diameter loss, stem segments are submitted to one heat shock cycle.

All the studied species have a hardiness zone rating indicating the geographic zone where they prevail in the USA (Dirr 2009; Table 1). DS irreversible during the cold-hardy stage correlated fairly well with the hardiness rating (Fig. 5): better than electrolyte leakage. This might be related to the dependency of $\mathrm{DS}_{\text {irreversible }}$ on other factors affecting species survival in cold environments, perhaps the ability of the living cells to refill xylem conduits (Holbrook and Zwieniecki 1999; Hölttä et al. 2006; Charrier et al. 2013a; Spicer 2014). $\mathrm{DS}_{\text {irreversible }}$ is affected not only by frost damage, but also by the total volume of living cells (and their elasticity), and thus, $\mathrm{DS}_{\text {irreversible }}$ may correlate with the refilling process of xylem conduits through the volume share of living cells in the branch volume.

Diameter changes were measured over bark indicating shrinkage of the whole branch. In general, the ratio between diameter fluctuations of the rigid xylem and the respective fluctuations of the elastic bark is typically known to be small (Zweifel and Häsler 2000; Steppe et al. 2012). Améglio et al. (2001a) found xylem to represent $15 \%$ of the total shrinkage observed during freezing in stem segments of $J$. regia of $1 \mathrm{~cm}$ in diameter. Thus, it can be assumed that also in our results, bark diameter changes play bigger role than xylem diameter changes.

Our approach was to compare two methods to indicate frost tolerance in seven species and in two stages of cold hardiness: the well-known method of electrolyte leakage and a lessknown method based on irreversible branch diameter shrinkage. For this purpose, a faster electrolyte leakage measurement in a given temperature of $-25{ }^{\circ} \mathrm{C}$ was considered to be 
sufficient for the main conclusions of the study. Also, the amount of available branch material was limited for the destructive measurements considering that we were studying urban trees. An additional test temperature of $-17{ }^{\circ} \mathrm{C}$ was added to verify the interpretation of the ion leakage results: electrolyte leakage was higher, and differences between seasons and species were similar in response to freezing to $-25{ }^{\circ} \mathrm{C}$ compared to $-17{ }^{\circ} \mathrm{C}$ as expected. The few slightly negative values in the index of injury, especially in cases where temperature was lowered to $-17{ }^{\circ} \mathrm{C}$ and electrolyte leakage was negligible, are due to limitations in measurement precision.

We used unnaturally high-temperature change rate of approximately $1{ }^{\circ} \mathrm{C} \mathrm{min}^{-1}$. In studies regarding the effect of cooling rate on cell damage, i.e., intracellular ice nucleation, irreversible plasmolysis, and breakage of the cell membranes due to apoplastic crystallization (Sakai and Larcher 1987; Pearce 2001; Han and Bischof 2004), cooling temperature of less than $10^{\circ} \mathrm{C} \mathrm{min}^{-1}$ has shown not to induce cell damage in trees (Sakai and Yoshika 1967; Quamme et al. 1973; Perkins and Adams 1995). Also, correlation of the results with the USDA hardiness rating suggests that no unnatural cell damage interfering with the irreversible diameter response was caused by the used cooling rate. To express species-specific frost tolerance in a more standardized form in future work, the temperature at $50 \%$ lethality (LT50) could be measured and at cooling rates that imitate natural frost events.

Urban trees grow in an unnatural environment that is stressful for trees in many ways: the belowground growth space for roots is limited and often inadequate to offer enough water and nutrients for growth; the microclimate is harsh with air pollutants, wind tunnels, and direct sunlight; artificial lights can induce perturbation in the annual cycle of trees; and trees frequently experience mechanical damage. The urban environment may possibly have made the studied tree individuals more vulnerable to freezing stress compared to individuals growing in natural conditions, especially as the studied trees were likely still experiencing some transplanting stress and associated changes, e.g., in their shoot/root ratio at the time of the experiments.

\section{Conclusions}

Our results suggest that the irreversible diameter shrinkage due to freezing stress is a good and non-destructive method to indicate frost tolerance. It also correlates with the USDA hardiness rating that is based on the minimum temperature range in which species prevail in the USA. $Q$. palustris and $C$. monogyna had the highest frost tolerance among the species of the study during the dehardening stage in early spring, whereas $P$. fraxinifolia was the least frost tolerant.
Acknowledgments This study was conducted in collaboration with the City of Helsinki Public Works Department.

Funding The study was funded by a 3-year research grant offered by the University of Helsinki and by the Academy of Finland (project no. 268342, Centre of Excellence grant no. 272041). This work has been carried out under the Nordic Center of Excellence CRAICC.

\section{References}

Améglio T, Cochard H, Ewers FW (2001a) Stem diameter variations and cold hardiness in walnut trees. J Exp Bot 52:2135-2142. doi:10. 1093/jexbot/52.364.2135

Améglio T, Cochard H, Ewers FW, Lacointe A, Leveque A (2001b) Cold hardiness: a new tool for testing acclimation. In: Labrecque M. (Ed.) L'Arbre 2000 The tree. Collection Collectif, I.Q. editeur, Montréal (Quebec) Canada, pp. 327-330

Améglio T, Ewers FW, Cochard H (2003a) GelistaTM: a new tool for testing frost hardiness by stem diameter variations. Acta Horticult 618:509-515

Améglio T, Pigeon D, Archilla O, Bodet C, Frizot N, Saint-Joanis B, Reynoird JP, Guillot A (2003b) Adaptation to cold temperature and response to freezing in roses. Acta Horticult 618:515-520

Bengtsson R (1998) Stadsträd från A till Z. AB Svensk Byggtjänst, Stockholm

Bohn M, Lüthje S, Sperling P, Heinz E, Dörffling K (2006) Plasma membrane lipid alterations induced by cold acclimation and abscisic acid treatment of winter wheat seedlings differing in frost resistance. J Plant Physiol 164:146-156. doi:10.1016/j.jplph.2005.12.008

Burke MJ, Gusta LV, Quamme HA, Weiser CJ, Li PH (1976) Freezing and injury in plants. Annu Rev Plant Physiol 27:507-528. doi:10. 1146/annurev.pp. 27.060176.002451

Charrier G, Améglio T (2011) The timing of leaf fall affects cold acclimation by interactions with air temperature through water and carbohydrate contents. Environ Exp Bot 72:351-357. doi:10.1016/j. envexpbot.2010.12.019

Charrier G, Cochard H, Améglio T (2013a) Evaluation of the impact of frost resistances on potential altitudinal limit of trees. Tree Physiol 33:891-902. doi:10.1093/treephys/tpt062

Charrier G, Poirier M, Bonhomme M, Lacointe A, Améglio T (2013b) Frost hardiness in walnut trees (Juglans regia L.): how to link physiology and modelling? Tree Physiol 33:1229-1241. doi:10.1093/ treephys/tpt090

Charrier G, Charra-Vaskou K, Kasuga J, Cochard H, Mayr S, Améglio T (2014) Freeze-thaw stress. Effects of temperature on hydraulic conductivity and ultrasonic activity in ten woody angiosperms. Plant Physiol 164:992-998. doi:10.1104/pp. 113.228403

Cochard H, Tyree MT (1990) Xylem dysfunction in Quercus: vessel sizes, tyloses, cavitation and seasonal changes in embolism. Tree Physiol 6:393-407. doi:10.1093/treephys/6.4.393

Davis SD, Sperry JS, Hacke UG (1999) The relationship between xylem conduit diameter and cavitation caused by freezing. Am J Bot 86: $1367-1372$

Dexter ST (1956) The evaluation of crop plants for winter hardiness. Adv Agron 8:203-239

Dirr MA (2009) Manual of woody landscape plants: their identification, ornamental characteristics, culture, propagation and uses, 6th edn. Stipes Publishing Company, Illinois

Doyle JA, Donoghue MJ (1992) Fossils and seed plant phylogeny reanalyzed. Brittonia 44:89-102. doi:10.2307/2806826

Flint HL, Boyce BR, Beattie DJ (1967) Index of injury-a useful expression of freezing injury to plant tissues as determined by the electrolytic method. Can J Plant Sci 47:229-230. doi:10.4141/cjps67-043 
Fujikawa S, Kuroda K (2000) Cryo-scanning electron microscopic study on freezing behavior of xylem ray parenchyma cells in hardwood species. Micron 31:669-686. doi:10.1016/S0968-4328(99)00103-1

George MF, Becwar MR, Burke MJ (1982) Freezing avoidance by deep undercooling of tissue water in winter-hardy plants. Cryobiol 19: 628-639. doi:10.1016/0011-2240(82)90192-4

Goldstein G, Rada F, Azocar A (1985) Cold hardiness and supercooling along an altitudinal gradient in andean giant rosette species. Oecologia 68:147-152. doi:10.1007/BF00379487

Gusta LV, Wisniewski M, Nesbitt NT, Gusta ML (2004) The effect of water, sugars, and proteins on the pattern of ice nucleation and propagation in acclimated and nonacclimated canola leaves. Plant Physiol 135:1642-1653. doi:10.1104/pp. 103.028308

Han B, Bischof JC (2004) Direct cell injury associated with eutectic crystallization during freezing. Cryobiol 48:8-21. doi:10.1016/j. cryobiol.2003.11.002

Holbrook NM, Zwieniecki MA (1999) Embolism repair and xylem tension: do we need a miracle? Plant Physiol 120:7-10. doi:10.1104/ pp.120.1.7

Hölttä T, Vesala T, Perämäki M, Nikinmaa E (2006) Refilling of embolised conduits as a consequence of 'Münch water' circulation. Funct Plant Biol 33:949-959. doi:10.1071/FP06108

Kuroda K, Kasuga J, Arakawa K, Fujikawa S (2003) Xylem ray parenchyma cells in boreal hardwood species respond to subfreezing temperatures by deep supercooling that is accompanied by incomplete desiccation. Plant Physiol 131:736-744. doi:10.1104/ pp.011601

Levitt J (1980) Responses of plants to environmental stress. Chilling, freezing, and high temperature stresses, 2nd edn. Academic, New York

Lindstrom OM, Anisko T, Dirr MA (1995) Low-temperature exotherms and cold hardiness in three taxa of deciduous trees. J Amer Soc Hort Sci 120:830-834

Lintunen A, Hölttä T, Kulmala M (2013) Anatomical regulation of ice nucleation and cavitation helps trees to survive freezing and drought stress. Sci Report 3:2031. doi:10.1038/srep02031

Morin X, Améglio T, Ahas R, Kurz-Besson C, Lanta V, Lebourgeois F, Miglietta F, Chuine I (2007) Variation in cold hardiness and carbohydrate concentration from dormancy induction to bud burst among provenances of three European oak species. Tree Physiol 27:817825. doi:10.1093/treephys/27.6.817

Pearce RS (1988) Extracellular ice and cell shape in frost-stressed cereal leaves: a low-temperature scanning-electron-microscopic study. Planta 175:313-324. doi:10.1007/BF00396336

Pearce RS (2001) Plant freezing and damage. Ann Bot 87:417-424. doi: 10.1006/anbo.2000.1352

Perkins TD, Adams GT (1995) Rapid freezing induces winter injury symptomatology in red spruce foliage. Tree Physiol 15:259-266. doi:10.1093/treephys/15.4.259

Pittermann J, Sperry JS (2003) Tracheid diameter is the key trait determining the extent of freezing-induced embolism in conifers. Tree Physiol 23:907-914. doi:10.1093/treephys/23.13.907

Pramsohler M, Hacker J, Neuner G (2012) Freezing pattern and frostkilling temperature of apple (Malus domestica) wood under controlled conditions and in nature. Tree Physiol 00:1-10. doi:10. 1093/treephys/tps046

Prášil I, Zámečník J (1998) The use of a conductivity measurement method for assessing freezing injury: I. Influence of leakage time, segment number, size and shape in a sample on evaluation of the degree of injury. Environ Exp Bot 40:1-10. doi:10.1016/S0098-8472(98) 00010-0

Quamme H, Weiser CJ, Stushnoff C (1973) The mechanism of freezing injury in xylem of winter apple twigs. Plant Physiol 51:273-277. doi:10.1104/ pp. 51. 2. 273
Ristic Z, Ashworth EN (1993) Ultrastructural evidence that intracellular ice formation and possibly cavitation are the sources of freezing injury of supercooling wood tissue of Cornus florida L. Plant Physiol 103:753-761. doi:10.1104/pp. 103.3. 753

Sakai A, Larcher W (1987) Frost survival of plants: responses and adaptations to freezing stress. Springer, Berlin

Sakai A, Yoshika S (1967) Survival of plant tissue at super-low temperature VI. Effects of cooling and rewarming rates on survival. Plant Physiol 42:1695-1701. doi:10.1104/pp. 42. 12. 1695

Sarvas R (1972) Investigations on the annual cycle of development of forest trees. Active period. Commun Inst For Fenn 76:1-110

Sperry JS, Sullivan JEM (1992) Xylem embolism in response to freezethaw cycles and water stress in ring-porous, diffuse-porous, and conifer species. Plant Physiol 100:605-613. doi:10.1104/pp.100.2. 605

Sperry JS, Nichols KL, Sullivan JEM, Eastlack SE (1994) Xylem embolism in ring-porous, diffuse-porous, and coniferous trees of northern Utah and interior Alaska. Ecology 75:1736-1752. doi:10.2307/ 1939633

Spicer R (2014) Symplasmic networks in secondary vascular tissues: parenchyma distribution and activity supporting long-distance transport. J Exp Bot 65:1829-1848. doi:10.1093/jxb/ert459

Steponkus PL (1984) Role of the plasma membrane in freezing injury and cold acclimation. Annu Rev Plant Physiol 35:543-584. doi:10.1146/ annurev.pp. 35.060184.002551

Steppe K, Cochard H, Lacointe A, Améglio T (2012) Could rapid diameter changes be facilitated by a variable hydraulic conductance? Plant Cell Environ 35:150-157. doi:10.1111/j.1365-3040.2011. 02424.x

Sutinen ML, Palta JP, Reich PB (1992) Seasonal differences in freezing stress resistance of needles of Pinus nigra and Pinus resinosa: evaluation of the electrolyte leakage method. Tree Physiol 11:241-254. doi:10.1093/treephys/11.3.241

Taiz L, Zeiger E (2006) Plant physiology, 4th edn. Sinauer Associates, Sunderland

Thomashow MF (1998) Role of cold responsive genes in plant freezing tolerance. Plant Physiol 118:1-7. doi:10.1104/pp. 118.1.1

Thomashow MF (1999) Plant cold acclimation: freezing tolerance genes and regulatory mechanisms. Annu Rev Plant Physiol Plant Mol Biol 50:571-599. doi:10.1146/annurev.arplant.50.1.571

Uemura M, Steponkus PL (2003) Modification of the intracellular sugar content alters the incidence of freeze-induced membrane lesions of protoplasts isolated from Arabidopsis thaliana leaves. Plant Cell Environ 26:1083-1096. doi:10.1046/j.1365-3040.2003.01033.x

Uemura M, Tominaka Y, Nakagawara C, Shigematsu S, Minami A, Kawamura Y (2006) Responses of the plasma membrane to low temperatures. Physiol Plantarum 126:81-89. doi:10.1111/j.13993054.2005.00594.x

Weiser CJ (1970) Cold resistance and injury in woody plants. Science 169:1269-1278. doi:10.1126/science.169.3952.1269

Wheeler JK, Sperry JS, Hacke UG, Hoang N (2005) Inter-vessel pitting and cavitation in woody Rosaceae and other vesselled plants: a basis for a safety versus efficiency trade-off in xylem transport. Plant Cell Environ 28:800-812. doi:10.1111/j.1365-3040.2005.01330.x

Wilson CJ, Jackson RB (2006) Xylem cavitation caused by drought and freezing stress in four co-occurring Juniperus species. Physiol Plant 127:374-382. doi:10.1111/j.1399-3054.2006.00644.x

Wisniewski M, Fuller M, Palta J, Carter J, Arora R (2004) Ice nucleation, propagation, and deep supercooling in woody plants. J Crop Improv 10:5-16. doi:10.1300/J411v10n01_02

Zweifel R, Häsler R (2000) Frost-induced reversible shrinkage of bark of mature subalpine conifers. Agric For Meteorol 102:213-222. doi: 10.1016/S0168-1923(00)00135-0 